\title{
HOW WILL CLIMATE CHANGE IMPACT THE STORM MAGNITUDE AND THROUFALL IN SEVERAL FOREST AREAS IN IRAN?
}

\author{
P. Attarod ${ }^{1, *}$, Q. Tang ${ }^{2}$, J.T. Van Stan II ${ }^{3}$, T. G. Pypker ${ }^{4}$, X. Liu ${ }^{2}$ \\ ${ }^{1}$ Forestry and Forest Economics Department, Faculty of Natural Resources, University of Tehran, Iran - (attarod@ut.ac.ir) \\ ${ }^{2}$ Key Laboratory of Water Cycle and Related Land Surface Processes, Institute of Geographic Sciences and Natural Resources \\ Research, Chinese Academy of Sciences, China - tangqh@igsnrr.ac.cn; xingcailiu@igsnrr.ac.cn \\ ${ }^{3}$ Department of Geology and Geography, Georgia Southern University, USA- jvanstan@ georgiasouthern.edu \\ ${ }^{4}$ Department of Natural Resource Sciences, Faculty of Science, Thompson Rivers University, Kamloops, Canada - \\ tgpypker@mtu.edu
}

KEY WORDS: Climate change, Forest ecosystems, General Circulation Models, Precipitation projection, Throughfall sensitivity

\begin{abstract}
:
Across all forest systems, the primary driver of throughfall (TF) amount is rainfall amount $\left(\mathrm{P}_{\mathrm{g}}\right)$ though no work has addressed the sensitivity of the TF response to projected shifts in $\mathrm{P}_{\mathrm{g}}$ due to climate change. We assessed how climate change may impact $\mathrm{TF}$ sensitivity to variability in $\mathrm{P}_{\mathrm{g}}$ for eleven typical forest sites across the main climate types of Iran using a nondimensional relative sensitivity coefficient. The Coupled Model Intercomparison Project phase 5 (CMIP5) HadGEM2-ES product was used under two emission scenarios (Representative Concentration Pathway (RCP) 2.6 and 8.5) to project yearly precipitation and $\mathrm{P}_{\mathrm{g}}$ for the measurement sites during 2020-50. There was a strong linear relationship between TF and $\mathrm{P}_{\mathrm{g}}$ at all sites $\left[\mathrm{TF}=0.66\left(\mathrm{P}_{\mathrm{g}}\right)-0.30 ; \mathrm{R}^{2}=\right.$ $0.91 ; n=639]$. The sensitivity coefficient ranged from 0.96-5.3 across the eleven forest sites. Large sensitivity coefficient differences were found between small ( $<$ mean annual $\mathrm{P}_{\mathrm{g}}$ ) and large $\left(>\right.$ mean annual $\mathrm{P}_{\mathrm{g}}$ ) storms for arid plantations. To buffer expected shifts in storm size due to climate change, it may be suitable to incorporate TF sensitivity when choosing landscaping and urban greening. Shifts in $\mathrm{Pg}_{\mathrm{g}}$ and increased small storm frequency are predicted for 2020-50 per CMIP5 HadGEM2-ES low and high emission scenarios.
\end{abstract}

\section{INTRODUCTION}

Climate change has significantly intensified the hydrologic cycle and, consequently, altered precipitation characteristics around the globe (Huntington, 2006). Global temperature has increased by 0.3 to $0.6^{\circ} \mathrm{C}$ since the late $19^{\text {th }}$ century and by 0.2 to $0.3^{\circ} \mathrm{C}$ over the past forty years (IPCC 2013). Global landsurface air temperature has increased in the Northern Hemisphere by $0.3^{\circ} \mathrm{C}$ per decade from 1979 to 2005 (Smith and Reynolds 2005; Brohan et al. 2006). Climate change has driven an increase in extreme precipitation events across most of the world (Tollefson, 2016).

A significant portion of rainfall is intercepted on forest canopy surfaces, where it is either returned to the atmosphere as interception (I) or redistributed to the ground as throughfall (TF) and stemflow (SF). Studies across forest ecosystems agree that rainfall amount $\left(\mathrm{Pg}_{\mathrm{g}}\right)$ is the principal variable driving throughfall (TF) amount (Levia \& Frost 2006; Levia et al. 2011). However, the authors are unaware of previous work (Sun et al. 2006; Wang et al. 2011), particularly for the $90 \%$ of Iran classified as arid or semi-arid (Ul Hassan et al. 2007). An improved understanding of TF sensitivity to climate change and $\mathrm{P}_{\mathrm{g}}$ is essential for addressing these concerns and quantifying the impacts of Iran's (and other nations') large-scale afforestation and reforestation efforts.

Researchers have developed models to simulate the current and future climates under different greenhouse gas scenarios (20.1\%) (Amiri and Eslamian 2010). To our knowledge, there has been no published research on the potential impact of quantifying $\mathrm{TF}$ sensitivity to changes in $\mathrm{P}_{\mathrm{g}}-\mathrm{a}$ commonly anticipated climate response to hydrologic intensification (Huntington, 2006). As ecohydrological interactions play key roles in ecosystem functioning, understanding TF's response to natural and anthropogenic variability is critical to forest management.

Hydrologic intensification has been linked to increased extreme $\mathrm{Pg}_{\mathrm{g}}$ in many regions (Tollefson, 2016). Moreover, afforestation, reforestation, urban forestry and other "greening" initiatives have grown in popularity and, therefore, increased the forest cover in most developed regions (i.e., McGovern \& Pasher, 2016). In Iran, for example, the restoration of semi-arid and arid ecosystems through planting of low-demand and drought tolerant species has become a critical element of national ecosystem management plans (Attarod et al. 2015b). Concerns have risen over the impact of these greening initiatives on the hydrological cycle (Buser et al. 2009). Global coupled Atmospheric-Ocean General Circulation Models (coupled GCMs) are used in theoretical investigations of climatic change (Covey et al. 2003). Projecting changes in $P_{g}$ is essential for Iran, where dry conditions may increase under global warming if no adaptation/mitigation solutions are undertaken (Karandish et al. 2016). Approximately $85 \%$ of Iran's terrestrial land area is categorized as hyper-arid (35.5\%), arid (29.2\%), and semi-arid climate change on $\mathrm{P}_{\mathrm{g}}$ partitioning in afforestations and natural forests of Iran. The objectives of this research were 1) to

\footnotetext{
* Corresponding author
} 
examine the sensitivity of TF across common forest species and afforestation commonly planted in Iran to $\mathrm{Pg}_{\mathrm{g}}$ size and 2) to assess how changing climate variables, as projected by GCMs, may impact future TF inputs. Accomplishing these aims will provide novel information to complement existing data used by forest managers during species selection for restoration and afforestation activities.

\section{MATERIAL AND METOD}

\subsection{Study sites}

Data were collected in 11 forest stands of several common native and introduced tree species (Table 1) situated in all common Iranian climate types (Table 2). The selected species represent a diversity of forest canopy architectures, ranging from the smooth-barked, broad-leaved canopy of Fagus orientalis (FO) to the rough-barked, needle-leaved canopy of Pinus eldarica (PE). Leaf phenology also differs among the selected species as, for example FO is deciduous and PE is evergreen.

Figure 1. Locations of the

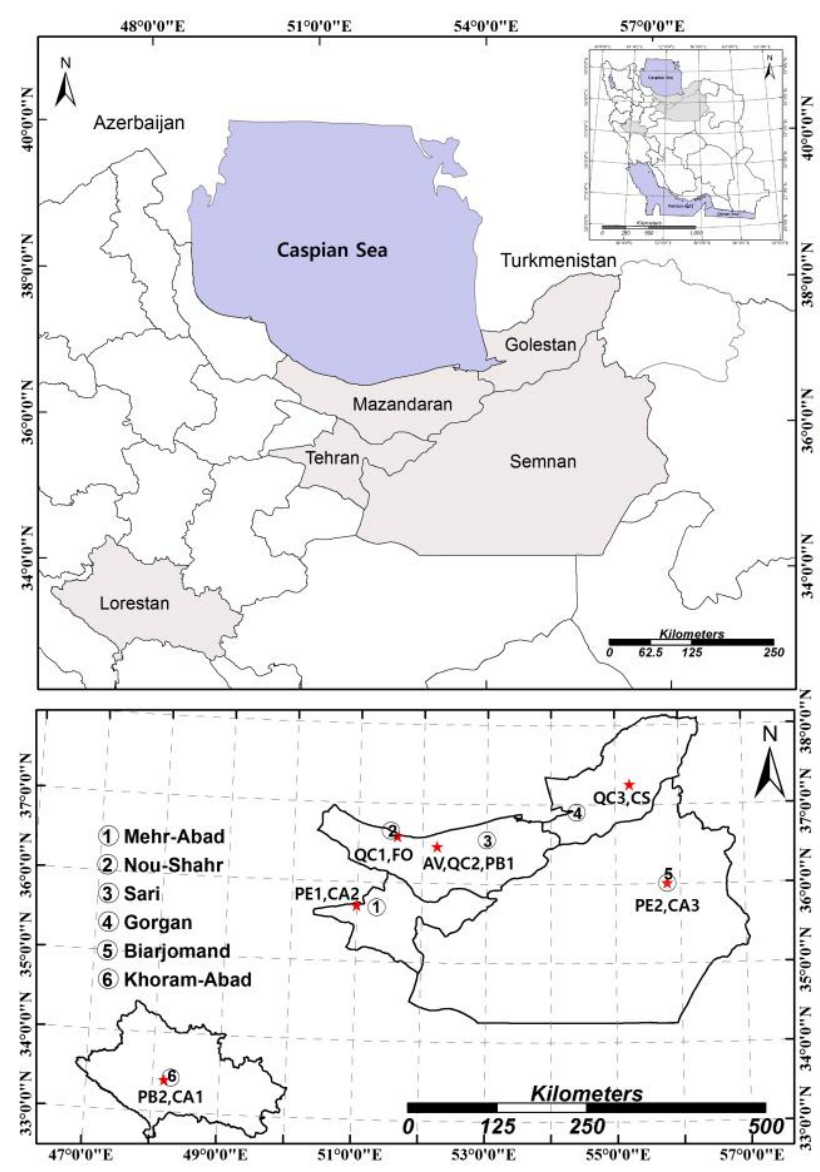

(triangles) and synoptic meteorological stations (numbers) in Iran. See Table 1 for species abbreviations.

Table 1. Forest sites where throughfall (TF) data were collected, including their climate, geographical coordinates, elevation, and stand characteristics. "G" and "D" refer to growing and dormant seasons, respectively, and dbh refers to diameter at breast height.

\begin{tabular}{|c|c|c|c|c|c|c|c|c|c|c|c|}
\hline Species & Code & Climate $^{\wedge}$ & $\begin{array}{c}\text { Elevation } \\
\text { (m) }\end{array}$ & Longitude & Latitude & $\begin{array}{l}\text { Mean dbh } \\
\quad(\mathrm{cm})\end{array}$ & $\begin{array}{c}\text { Mean height } \\
\text { (m) }\end{array}$ & $\begin{array}{c}\text { Closure } \\
(\%)\end{array}$ & $\begin{array}{c}\text { Density } \\
\left.\left(\text { trees }^{-1}\right)^{-1}\right)\end{array}$ & $\begin{array}{l}\text { Study period } \\
\quad \text { (year) }\end{array}$ & $\begin{array}{c}\text { Storms } \\
\text { (n) }\end{array}$ \\
\hline Fagus orientalis & FO & VH & 1410 & $51^{\circ} 37^{\prime}$ & $36^{\circ} 35^{\prime}$ & 50 & 32 & 95 & 112 & $08,09(\mathrm{G})$ & 53 \\
\hline Quercus castaneifolia & $\mathrm{QC}_{1}$ & VH & 1550 & $51^{\circ} 37^{\prime}$ & $36^{\circ} 35^{\prime}$ & 36 & 28 & 80 & 175 & $09,10(\mathrm{G})$ & 28 \\
\hline Quercus castaneifolia & $\mathrm{QC}_{2}$ & SH & 360 & $52^{\circ} 14^{\prime}$ & $36^{\circ} 28^{\prime}$ & 21 & 18 & 70 & 864 & $12(\mathrm{G})$ & 20 \\
\hline Acer velutinum & $\mathrm{AV}$ & SH & 360 & $52^{\circ} 14^{\prime}$ & $36^{\circ} 28^{\prime}$ & 20 & 19 & 80 & 292 & $12(\mathrm{G})$ & 20 \\
\hline Pinus brutia* & $\mathrm{PB}_{1}$ & SH & 360 & $52^{\circ} 14^{\prime}$ & $36^{\circ} 28^{\prime}$ & 14 & 12 & 85 & 541 & $12(\mathrm{G})$ & 20 \\
\hline Quercus castaneifolia & $\mathrm{QC}_{3}$ & M & 250 & $55^{\circ} 14^{\prime}$ & $37^{\circ} 15^{\prime}$ & 65 & 21 & 55 & 198 & $13(\mathrm{G})$ & 24 \\
\hline
\end{tabular}




\begin{tabular}{|c|c|c|c|c|c|c|c|c|c|c|c|}
\hline $\begin{array}{l}\text { Cupressus sempervirens } \\
\quad \text { var. horizontalis }\end{array}$ & $\mathrm{CS}$ & M & 250 & $55^{\circ} 14^{\prime}$ & $37^{\circ} 15^{\prime}$ & 12 & 7 & 70 & 1600 & $13(\mathrm{G})$ & 24 \\
\hline Pinus brutia ${ }^{*+}$ & $\mathrm{PB}_{2}$ & SA & 1250 & $48^{\circ} 11^{\prime}$ & $33^{\circ} 24^{\prime}$ & 20 & 7 & --- & 1000 & $13(\mathrm{G})$ & 15 \\
\hline Cupressus arizonica $^{*+}$ & $\mathrm{CA}_{1}$ & SA & 1250 & $48^{\circ} 11^{\prime}$ & $33^{\circ} 24^{\prime}$ & 15 & 6 & --- & 1000 & $13(\mathrm{G})$ & 15 \\
\hline Pinus eldarica* & $\mathrm{PE}_{1}$ & A & 1220 & $51^{\circ} 08^{\prime}$ & $35^{\circ} 42^{\prime}$ & 22 & 9 & 60 & 1020 & $11-14(\mathrm{G}, \mathrm{D})$ & 165 \\
\hline Cupressus arizonica* & $\mathrm{CA}_{2}$ & A & 1220 & $51^{\circ} 08^{\prime}$ & $35^{\circ} 42^{\prime}$ & 20 & 8 & 45 & 960 & $11-14(\mathrm{G}, \mathrm{D})$ & 165 \\
\hline Pinus eldarica ${ }^{*+}$ & $\mathrm{PE}_{2}$ & A & 1091 & $55^{\circ} 48^{\prime}$ & $36^{\circ} 04^{\prime}$ & 30 & 8 & --- & 2500 & 08-09 (G, D) & 26 \\
\hline Cupressus arizonica $^{*+}$ & $\mathrm{CA}_{3}$ & A & 1091 & $55^{\circ} 48^{\prime}$ & $36^{\circ} 04^{\prime}$ & 25 & 6 & --- & 2500 & $08-09(\mathrm{G}, \mathrm{D})$ & 26 \\
\hline
\end{tabular}

*Non-native; ${ }^{+}$Individual trees; ${ }^{\wedge}$ VH: Very humid, SH: Semi-humid, M: Mediterranean, A: Arid, SA: Semi-arid

Meteorological data were obtained from the nearest synoptic meteorological stations recording reliable long-term meteorological data (Fig. 1). The range in meteorological data records is from 1951 to 2016 (Table 2). There exists relatively long distances between the Mehr-Abad, Sari, and Gorgan meteorological stations (Fig. 1), but there is no significant topography between the measurement sites and the meteorological stations, and no closer meteorological stations exist in the region. Due to lack of meteorological station inside the Caspian forest, we used meteorological data recorded by
Nou-Shahr meteorological station regardless of elevation difference. The ranges of annual precipitation $(\mathrm{P})$ and temperature $(\mathrm{T})$ in the weather station sites are $16.4-17.4^{\circ} \mathrm{C}$ and 230-1291 mm, respectively (Table 2). The "De Martonne", climate classification, i.e., De Martonne aridity index (IDM), as described by Baltas (2007), ranged roughly from 49 to 5 , so that the study sites were grouped into very humid $\left(\mathrm{FO}, \mathrm{QC}_{1}\right)$, semihumid $\left(\mathrm{QC}_{2}, \mathrm{AV}, \mathrm{PB}_{1}\right)$, Mediterranean $\left(\mathrm{QC}_{3}, \mathrm{CS}\right)$, semi-arid $\left(\mathrm{PE}_{2}, \mathrm{CA}_{1}\right)$ and arid $\left(\mathrm{PE}_{1}, \mathrm{CA}_{2}, \mathrm{PE}_{2}, \mathrm{CA}_{3}\right)$ climates (Table 1).

Table 2. Details of weather stations included in this study, their climate types according to the de Martonne aridity index ( $I_{D M}$ : Baltas, 2007), and the duration of their measurement record.

\begin{tabular}{|c|c|c|c|c|c|c|c|c|}
\hline Station & Dates of record & $\begin{array}{l}\text { Elevation } \\
(\mathrm{m} \text { asl })\end{array}$ & Longitude & Latitude & Annual temperature $\left({ }^{\circ} \mathrm{C}\right)$ & Annual precipitation (mm) & $\begin{array}{l}\text { Mean precipitation } \\
\quad \text { size }(\mathrm{mm})\end{array}$ & Climate ( $I_{D M}$ value) \\
\hline Nou-Shahr & $1977-2015$ & -21 & $51^{\circ} 30^{\prime}$ & $36^{\circ} 39^{\prime}$ & 16.4 & 1291 & 10.5 & Very humid (49) \\
\hline Sari & $1985-2015$ & 23 & $53^{\circ} 00^{\prime}$ & $36^{\circ} 33^{\prime}$ & 16.9 & 742 & 7.2 & Semi-humid (27) \\
\hline Gorgan & $1955-2015$ & 0 & $54^{\circ} 24^{\prime}$ & $36^{\circ} 54^{\prime}$ & 17.8 & 572 & 6.0 & Mediterranean (21) \\
\hline Khoram-Abad & $1951-2016$ & 1150 & $48^{\circ} 17^{\prime}$ & $33^{\circ} 26^{\prime}$ & 17.4 & 495 & 8.6 & Semi-arid (14) \\
\hline Mehr-Abad & $1951-2015$ & 1191 & $51^{\circ} 19^{\prime}$ & $35^{\circ} 41^{\prime}$ & 17.4 & 230 & 3.9 & Arid (8) \\
\hline Biarjomand & $1992-2016$ & 1099 & $55^{\circ} 48^{\prime}$ & $36^{\circ} 05^{\prime}$ & 16.3 & 124 & 2.7 & Arid (5) \\
\hline
\end{tabular}

Field measurements were preformed from July-2008 to March2014 during growing and dormant seasons (Table 1). A discrete rain event was defined as a period with $>0.1 \mathrm{~mm}$ of rainfall. The minimum inter-event dry period between discrete storms was 4$10 \mathrm{~h}$, depending on the site. Snowfall was ignored. $\mathrm{P}_{\mathrm{g}}$ at each forest site was measured by 3-10 funnel-type plastic collectors with $10 \mathrm{~cm}$ funnel diameter and $20-30 \mathrm{~cm}$ heights, placed in the nearest open area away from the forest stands. The average of water amount measured in all rain-gauges at a site was used to estimate $\mathrm{Pg}_{\mathrm{g}}$ for each site. Quantities of water in the collectors were measured manually using a graduated cylinder. $\mathrm{Pg}$ volumes were measured at the same time as TF volumes at each site, either immediately after a storm or at sunrise following a

\subsection{TF sensitivity coefficients}

A practical method of presenting a sensitivity analysis is to plot relative changes of a dependent variable (in this case, TF) against relative change of an independent variable (i.e., $\mathrm{Pg}$ ) as a curve (e.g., Singh \& Xu, 1997; Goyal, 2004, Attarod et al. 2015a). This is different from a standard regression of TF versus $P_{g}$ as the mean sensitivity coefficient is calculated as the slope of a correlation between the percent changes in $\mathrm{P}_{\mathrm{g}}$ against percent changes in TF. The sensitivity coefficient represents the fraction of change in $\mathrm{Pg}_{\mathrm{g}}$ transmitted to the change of TF, i.e. a night storm. TF was measured using 20-50 rain collectors of the same design as those used to quantify $\mathrm{P}_{\mathrm{g}}$. TF collectors were randomly distributed beneath the canopy and fabric covered the neck of the collectors to avoid litter, needles, and debris from entering (Abbasian et al. 2015). For individual trees, the experimental network for each tree consisted of $8 \mathrm{TF}$ gauges at four main orientations $-\mathrm{N}, \mathrm{W}, \mathrm{S}$, and $\mathrm{E}$ (two gauges per direction) on the ground beneath the CPA of each tree in a radial layout centered on the tree trunk ( 8 gauges per tree, 40 gauges per species, and 80 gauges in total). Variability about mean $\mathrm{Pg}$ and $\mathrm{TF}$ will be expressed in standard error (SE) throughout.

sensitivity value of 0.1 would suggest that a $10 \%$ increase in $\mathrm{Pg}_{\mathrm{g}}$ may be predictable to increase TF by $1 \%$. Negative coefficients would indicate that a decrease in TF would result from an increase of $\mathrm{P}_{\mathrm{g}}$, which is not expected due to the universally reported positive relationship between $\mathrm{P}_{\mathrm{g}}$ and TF (Friesen . 2015). In the present study, the sensitivity coefficient of TF was determined in climate classifications only in response to changes in $\mathrm{Pg}_{\mathrm{g}}$ on an event-basis.

\subsection{Projected changes in precipitation and individual events}


Future climate data in grids with $0.5^{\circ} \times 0.5^{\circ}$ horizontal resolution were obtained from the HadGEM2-ES model projections for the measurement sites (Hempel et al. 2013). This model is a state-of-the-art general circulation model (GCM) (Jones et al. 2011). The HadGEM2-ES climate data has been extensively used for climate studies (Huntingford et al. 2013). The rli1p1 ensemble of HadGEM2-ES was used in this study. The r1ilp1 ensemble is the most accessible one in the CMIP5 archive. To

\subsection{Delta change (DC) method}

Because of the limitations of coarse-resolution GCM climate data (used in all of these predictions), the delta change (DC) method is generally used to derive regional predictions of future climate (e.g., Shahid 2011; Chung and Nkomozepi 2012). The precipitation for future time periods were derived by scaling the observed climate data, OBS (for the historical record) by the predicted climate change as computed by the GCMs. This results in a new time series for the future that is predicted using GCMs but modified using actual historical observations. In this

\section{RESULTS}

Strong positive linear relationships between event mean $\mathrm{TF}$ and $\mathrm{P}_{\mathrm{g}}$ were observed across all sites $\left[\mathrm{TF}=0.66\left(\mathrm{P}_{\mathrm{g}}\right)-0.30 ; \mathrm{R}^{2}=\right.$ 0.91] and at each individual site (Table 3). Slopes of the regression lines between $\mathrm{TF}$ and $\mathrm{Pg}$ (often assumed to be linked to varying canopy structures) were wide-ranging: 0.39 for $\mathrm{CS}$ to 0.85 for $\mathrm{CA}_{3}$ (Table 4). Relative TF (TF: $\mathrm{P}_{\mathrm{g}}$ ) varied from $33 \%$ (Arid $\mathrm{PE}_{3}$ ) to $75 \%$ (very humid $\mathrm{QC}_{1}$ ) (Table 3). In arid and TF: $\mathrm{P}_{\mathrm{g}}$ under arid conditions $\left(\mathrm{PE}_{3}: 32.8 \%\right.$ ) (Table 3). Generally higher standard errors were observed for TF: $\mathrm{P}_{\mathrm{g}}$ in the semi-arid understand precipitation variations under changing climate at the measurement sites, we focused on the precipitation projections for two scenarios: Representative Concentration Pathway (RCP) 2.6 and 8.5. They represent "low" and "high" emissions scenarios $\left(\mathrm{CO}_{2}\right.$ concentrations $=421 \mathrm{ppm}$ and 936 ppm by 2100 , respectively) that result in a radiative forcing equal to $2.6 \mathrm{Wm}^{-2}$ and $8.5 \mathrm{Wm}^{-2}$, respectively.

method consists of scaling the observed climate data using monthly change factors calculated from the differences in climate predicted by GCMs for the current and future periods. Using this methodology, study, the OBS from 1974 to 2004 (reference period) were scaled to derive the 30-yr future climate scenario for the period 2020-2050.

\subsection{Overview of rainfall and throughfall events}

Mediterranean climates, minimum TF: $\mathrm{Pg}$ were measured at zero, however, in other climates the minimum was approximately $47 \%$ (Table 3 ). TF:Pg in average was higher for broad-leaved forests $(63 \%)$ compared with the needle-leaved forests (48\%) across the climate zones (Table 3). For all sites, QC produced the highest TF: $\mathrm{P}_{\mathrm{g}}$ in very humid conditions $\left(\mathrm{QC}_{1}\right.$ : $74.5 \%)$ and the lowest site $(5 \%)$ and arid sites (4.3\%) compared to forests in other climates $(1.9 \%)$ (Table 3$)$.

Table 3. Relationships between throughfall (TF) and rain event magnitude $\left(\mathrm{Pg}_{\mathrm{g}}\right)$, percent of event based average relative throughfall (TF: $\left.\mathrm{P}_{\mathrm{g}}\right)$, and related statistics. See Table 1 for the tree species represented by the location codes. $\mathrm{n}$ refers to the number of recorded events.

\begin{tabular}{|c|c|c|c|c|c|c|c|}
\hline Tree species & $\mathrm{n}$ & Mean TF: $\mathrm{Pg}_{\mathrm{g}}(\%)$ & Max TF: $P_{g}(\%)$ & Min TF: $P_{g}(\%)$ & SE TF: $P_{g}(\%)$ & Regression & $r^{2}$ \\
\hline$F O$ & 53 & 69.4 & 85.0 & 52.1 & 1.3 & $\mathrm{TF}=0.81 \mathrm{Pg}-1.60$ & 0.98 \\
\hline$Q C_{l}$ & 28 & 74.5 & 87.8 & 60.1 & 1.1 & $\mathrm{TF}=0.80 \mathrm{Pg}-0.92$ & 0.99 \\
\hline$Q C_{2}$ & 20 & 66.4 & 80.0 & 45.4 & 1.3 & $\mathrm{TF}=0.70 \mathrm{Pg}_{\mathrm{g}}-0.17$ & 0.97 \\
\hline$A V$ & 20 & 44.2 & 59.2 & 30.9 & 1.3 & $\mathrm{TF}=0.54 \mathrm{P}_{\mathrm{g}}-1.03$ & 0.96 \\
\hline$P B_{1}$ & 20 & 59.0 & 78.6 & 43.7 & 1.7 & $\mathrm{TF}=0.62 \mathrm{P}_{\mathrm{g}}-0.55$ & 0.91 \\
\hline$Q C_{3}$ & 24 & 58.4 & 88.3 & 0 & 3.1 & $\mathrm{TF}=0.57 \mathrm{P}_{\mathrm{g}}-0.88$ & 0.87 \\
\hline CS & 24 & 39.3 & 76.0 & 0 & 3.4 & $\mathrm{TF}=0.39 \mathrm{P}_{\mathrm{g}}-0.64$ & 0.80 \\
\hline$P B_{2}$ & 15 & 47.0 & 66.7 & 2.3 & 4.8 & $\mathrm{TF}=0.53 \mathrm{Pg}-0.09$ & 0.90 \\
\hline$C A_{l}$ & 15 & 54.6 & 79.2 & 8.4 & 5.0 & $\mathrm{TF}=0.61 \mathrm{P}_{\mathrm{g}}-0.09$ & 0.91 \\
\hline$P E_{l}$ & 165 & 50.7 & 86.8 & 0 & 3.9 & $\mathrm{TF}=0.79 \mathrm{Pg}-0.50$ & 0.98 \\
\hline $\mathrm{CA}_{2}$ & 165 & 55.8 & 89.2 & 6.0 & 2.8 & $\mathrm{TF}=0.73 \mathrm{Pg}-0.34$ & 0.97 \\
\hline$P E_{2}$ & 26 & 32.8 & 79.9 & 0 & 5.0 & $\mathrm{TF}=0.70 \mathrm{Pg}-0.64$ & 0.95 \\
\hline $\mathrm{CA}_{3}$ & 26 & 46.6 & 91.1 & 6.0 & 5.4 & $\mathrm{TF}=0.85 \mathrm{Pg}-0.60$ & 0.97 \\
\hline
\end{tabular}

\subsection{Throughfall sensitivity to changes in storm magnitude}

TF exhibited varying degrees of sensitivity to $\mathrm{P}_{\mathrm{g}}$, showing large fluctuations for species planted in different climates (Fig. 2). TF from the arid $\mathrm{PE}_{2}$ forest was most sensitive to fluctuations in $\mathrm{Pg}_{\mathrm{g}}$
(= 5.3) and $\mathrm{TF}$ from the Mediterranean $\mathrm{QC}_{3}$ forest was least sensitive $(=0.96)$ (Fig. 2). Needle-leaved plantations (i.e., PE, CA) generally had higher sensitivity $(>1.5)$ to changing $\mathrm{P}_{\mathrm{g}}$ compared to broadleaved forests $(\sim 1.0)$ (Fig. 2). For broadleaved forests, $\mathrm{QC}_{1}$ was less sensitive than $\mathrm{FO}$ in a very 
humid climate (Fig. 2). $\mathrm{QC}_{1}, \mathrm{QC}_{2}$, and $\mathrm{QC}_{3}$ had similar sensitivity coefficients regardless of climate: very humid $(=1.09)$ to semi-humid (=1.07) and Mediterranean climates $(=$ 0.96) (Fig. 2). TF sensitivity was tested for larger and smaller storm sizes than the mean $\mathrm{Pg}_{\mathrm{g}}$ in each climate (Table 4). Excluding $\mathrm{AV}, \mathrm{PB}_{1}$, and $\mathrm{QC}_{1}$, $\mathrm{TF}$ was found to be more sensitive to small storms (Table 4). Plantations in arid or Mediterranean climates had large differences in sensitivity coefficient between small and large events, e.g. 2.95 vs. 1.14 for PE and 1.78 vs. 0.74 for CS plantation (Table 4). Individual $\mathrm{PE}_{2}$ trees situated in the arid climate exhibited the largest sensitivity coefficient differences (3.4) between small and large $\mathrm{P}_{\mathrm{g}}$. However, individual CA trees showed smaller sensitivity coefficient differences when located in an arid climate (1.6) relative to a semi-arid climate (1.9). Interestingly, the FO forest had nearly identical sensitivity values for storms smaller (1.06) and larger (1.05) than mean $\mathrm{Pg}_{\mathrm{g}}$ (Table 4). Sensitivity of the very humid $\mathrm{QC}_{1}$ natural forest was greater for large events (1.07 against 1.24) in comparison with the semi-humid $\mathrm{QC}_{2}$ and Mediterranean $\mathrm{QC}_{3}$ forests (Table 4).

Table 4. Throughfall (TF) sensitivity coefficients classified for storm magnitudes $\left(\mathrm{P}_{\mathrm{g}}\right)$ smaller and larger than mean $\mathrm{Pg}_{\mathrm{g}}$ recorded in the measurement sites. See Table 1 for the tree species represented by the location codes.

\begin{tabular}{cccc}
\hline Tree species & $\begin{array}{c}\text { Mean } \mathrm{P}_{\mathrm{g}} \\
(\mathrm{mm})\end{array}$ & $\begin{array}{c}\text { Mean sensitivity for } \\
<\operatorname{mean} \mathrm{Pg}\end{array}$ & $\begin{array}{c}\text { Mean sensitivity for } \\
>\text { mean } \mathrm{Pg}\end{array}$ \\
\hline$F O$ & 18.9 & 1.06 & 1.05 \\
$Q C_{1}$ & 23.2 & 1.07 & 1.24 \\
$Q C_{2}$ & 17.3 & 1.08 & 0.81 \\
$A V$ & 17.3 & 1.14 & 1.34 \\
$P B_{1}$ & 17.3 & 0.96 & 1.45 \\
$Q C_{3}$ & 19.4 & 1.20 & 0.80 \\
$C S$ & 19.4 & 1.78 & 0.74 \\
$P B_{2}$ & 8.6 & 1.82 & 0.83 \\
$C A_{l}$ & 8.6 & 2.73 & 0.82 \\
$P E_{1}$ & 4.4 & 2.95 & 1.14 \\
$C A_{2}$ & 4.4 & 1.57 & 1.21 \\
$P E_{2}$ & 3.9 & 4.7 & 1.29 \\
$C A_{3}$ & 3.9 & 2.75 & 1.09 \\
\hline
\end{tabular}

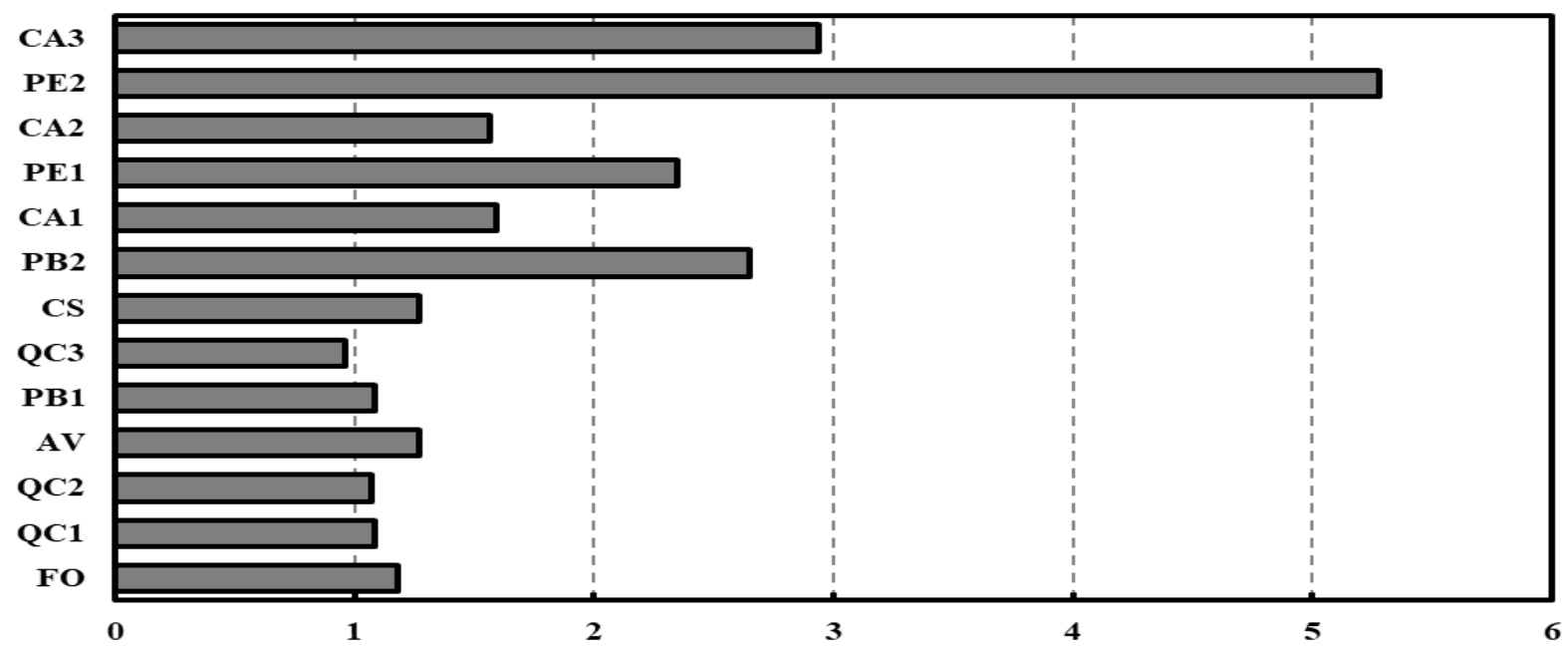

gure 2. Mean throughfall (TF) sensitivity coefficients for the measurement sites. See Table 1 for the tree species represented by the location codes.

\subsection{Projected changes in annual precipitation and storm magnitude}

During the 2020-2050 period, the low emissions (RCP 2.6) scenario predicted increased annual precipitation on average in all climate types, excluding the semi-humid and semi-arid climates, yet the high emissions (RCP 8.5) scenario predicted decreased annual precipitation on average in all climates excluding the arid climate (Table 5). Mean yearly precipitation is predicted to increase in the areas situated within the arid climates of Iran by $+30 \%$ but decrease in the semi-arid by roughly $-13.5 \%$.

Projected changes to mean $\mathrm{P}_{\mathrm{g}}$ from the low emission scenario was $+3 \%,-3 \%,+17.0 \%,-26.0 \%,-5 \%$ (average) for very humid, semi-humid, Mediterranean, semi-arid, and arid forests, respectively (Tables 5). The high emissions scenario predicts that mean $\mathrm{P}_{\mathrm{g}}$ will change by $-5 \%$ in very humid forests and - 
$10 \%$ in arid forests, but mean $\mathrm{P}_{\mathrm{g}}$ will not change for forests in the Mediterranean and semi-humid climates (Table 5).

Table 5. Projections of annual precipitation, and mean storm magnitude $\left(\mathrm{P}_{\mathrm{g}}\right)$ during the period of 2020-2050 predicted by the GCM under RCP 2.6 (low emission), and RCP 8.5 (high emission) scenarios. SE: standard error of mean of mean

\begin{tabular}{|c|c|c|c|c|}
\hline \multirow[t]{2}{*}{ Climate } & \multicolumn{3}{|c|}{ Annual precipitation (mm) } & \multirow{2}{*}{$\frac{\mathrm{Pg}_{\mathrm{g}}(\mathrm{mm})}{\text { Mean }}$} \\
\hline & Mean \pm SE & Max. & Min. & \\
\hline \multicolumn{5}{|l|}{ Very humid } \\
\hline RCP 2.6 & $1306 \pm 34$ & 1587 & 871 & 10.8 \\
\hline RCP 8.5 & $1207 \pm 31$ & 1489 & 845 & 10.0 \\
\hline \multicolumn{5}{|l|}{ Semi-humid } \\
\hline RCP 2.6 & $736 \pm 28$ & 989 & 563 & 7.0 \\
\hline RCP 8.5 & $670 \pm 24$ & 903 & 515 & 7.2 \\
\hline \multicolumn{5}{|l|}{ Mediterranean } \\
\hline RCP 2.6 & $598 \pm 18$ & 867 & 405 & 7.0 \\
\hline RCP 8.5 & $518 \pm 16$ & 743 & 357 & 6.0 \\
\hline \multicolumn{5}{|l|}{ Semi-arid } \\
\hline RCP 2.6 & $420 \pm 20$ & 706 & 214 & 5.3 \\
\hline RCP 8.5 & $436 \pm 19$ & 682 & 231 & 5.1 \\
\hline \multicolumn{5}{|l|}{ Arid } \\
\hline RCP 2.6 & $271 \pm 13$ & 448 & 144 & 3.9 \\
\hline RCP 8.5 & $247 \pm 11$ & 391 & 139 & 3.5 \\
\hline \multicolumn{5}{|l|}{ Arid } \\
\hline RCP 2.6 & $181 \pm 9$ & 258 & 88 & 2.7 \\
\hline RCP 8.5 & $167 \pm 9$ & 232 & 81 & 2.7 \\
\hline
\end{tabular}

\section{DISCUSSION}

\subsection{Storm magnitude and throughfall}

We collected a wide range of storms across sites hosting common forests in all of Iran's climate types (Table 1; Fig. 1). Relationships between $\mathrm{Pg}_{\mathrm{g}}$ and $\mathrm{TF}$ for individual forest often indicate differences in the canopy-meteorological interactions that control TF production by plants (Zhang et at., 2016). In this study, as in others, $\mathrm{P}_{\mathrm{g}}$ accounted for most of TF variability regardless the species, yet the slope and intercept of the $\mathrm{P}_{\mathrm{g}}$-TF correlation varied across the forests of differing species-climate combination (Table 4). Relative TF: $\mathrm{P}_{\mathrm{g}}$ in our study, 32.8$74.5 \%$, appears to be strongly tied to forest structure (e.g., density, seasonal change, vegetation area index, gap fraction, and canopy storage capacity), and climate conditions ( $\mathrm{P}_{\mathrm{g}}$ and, perhaps storm intensity and wind conditions) as shown by many others (Crockford \& Richardson, 2000; Staelens et al. 2008; Muzylo et al. 2012; Motahari et al. 2013). Results indicated that, when the same species experiences different climate conditions, they can differentially partition $\mathrm{Pg}_{\mathrm{g}}$ into $\mathrm{TF}$ - something particularly evident QC in three different climates (Table 3). We also observed rainfall events that produced no TF beneath PE trees in the arid climate because of complete interception by leaves/needles, branches, trunks, and stems of trees (Table 3).

\subsection{Throughfall sensitivity to storm amount}

Large fluctuations in TF sensitivity were observed between different species, climate types, and storm sizes (greater or less than mean annual $\mathrm{Pg}_{\mathrm{g}}$ ) common to Iran (Table 4). For forest managers, it is apparent that different species selected for planting in different climates will exhibit differing $\mathrm{TF}$ sensitivities to shifting $P_{g}$ (Fig. 2). Practically, managers can use these sensitivity coefficients (Fig. 2 or Table 4) and projected changes to $\mathrm{P}_{\mathrm{g}}$ (Tables 5) and estimate the potential shift in TF supply to the forest surface. For example, PE's sensitivity coefficient (2.35) indicates that a $10 \%$ decrease in $\mathrm{Pg}$ could approximately reduce $\mathrm{TF}$ by $23 \%$. Greater sensitivity coefficients for PE (and CA) plantations compared with other stands may be a result of (1) these species having larger storage capacities than other tree species in this study (Sadeghi et al. 2015), (2) their arid climate allowing their canopies to dry more efficiently between storms, and (3) most-to-nearly all the storms being small (Table 4). Moreover, our data suggests that a $10 \%$ decrease in $\mathrm{Pg}$ decreases $\mathrm{TF}$ generation by approximately $53 \%$ and $30 \%$ per event for PE and CA individual trees, respectively, in the arid climate. In the semiarid climate, a $10 \%$ decrease in $\mathrm{Pg}$ results in a $26 \%$ and $16 \%$ decline for $\mathrm{PB}$ and $\mathrm{CA}$ trees, respectively. The higher sensitivity of $\mathrm{PE}, \mathrm{PB}$, and $\mathrm{CA}$ to $\mathrm{Pg}_{\mathrm{g}}$ has implications for foresters dealing with climate change since these species are most widely-used species for afforestation in the arid and semiarid regions of Asia (e.g., Iran, Lebanon, Syria, Pakistan, Iraq, and Afghanistan) and are frequently selected due to their greater tolerance to drought, high/low temperature extremes, and being faster-growing than native broad- or needle-leaved tree species (Jazirei, 2009). Under a changing climate, water resource management in arid regions is therefore complicated by afforestation initiatives and forest managers may be able to use TF sensitivity as a variable in their decision to choose a species with the least sensitivity to expected shifts in $\mathrm{P}_{\mathrm{g}}$.

The remaining species located in the Caspian forests of northern Iran with very humid, semi-humid and Mediterranean climates exhibited roughly the same sensitivity (mean 1.13; Fig. 2). However, according to our results, the replacement of $\mathrm{QC}_{3}$ natural forest with introduced CS man-made in the Mediterranean areas of the eastern Caspian region will likely increase TF sensitivity by 0.31 (Fig. 2). This increased TF sensitivity with converting Mediterranean QC forests to CS may be a product of greater tree density of young CS (Table 1) or, more theoretically, greater roughness lengths and zero-plane displacement heights (Rutter et al. 1975; Valente et al. 1997). Moreover, CS's scale-like needle-leaves have different leaf shedding habits compared to $\mathrm{QC}_{3}$ 's broadleaves, which will differentially interact with $\mathrm{Pg}_{\mathrm{g}}$ to alter $\mathrm{TF}$ and its sensitivity (Pypker et al. 2011).

Natural broad-leaved forests in the Caspian region (FO and $\mathrm{QC}_{1}$ ) showed roughly the same sensitivity (Fig. 2). The primary function of the Caspian forests, other than wood production, is conservation of soil and water resources (Sagheb Talebi et al. 2014). Thus, it is expected that the low TF sensitivity of FO and $\mathrm{QC}_{1}$ to shifts in $\mathrm{P}_{\mathrm{g}}$ will help buffer the region against climate changes. But, restoration of the Caspian deciduous forest of northern Iran by planting exotic species, like CS (which had a greater TF sensitivity coefficient), were extensively performed by Iran's Forest, Rangeland, and Watershed organization, and may have considerable effects on ecosystem ecohydrology through altered TF supply. In contrast, introduction of $\mathrm{PB}_{1}$ in the semi humid climate of the central Caspian region for restoration of degraded forests showed roughly the same, even lower, sensitivity compared to natural species ( $\mathrm{AV}$ and $\mathrm{QC}_{2}$ ) (Fig. 2). Thus, understanding the relationship between hydrologic cycling and the impact of afforestation projects on these variables can be useful for forest management and selection of suitable species for reforestation of degraded forest ecosystems.

Climate change complicates water resource management in arid and semi-arid regions. When planting afforestations, forest managers may be able to use TF sensitivity to help choose a species with the least sensitivity to expected shifts in $\mathrm{P}_{\mathrm{g}}$ size. 
TF sensitivity, like $\mathrm{Pg}$ partitioning, is attributed to structural differences when comparing tree species in the same region with similar climate factors (Crockford and Richardson, 2000). Branching architecture, like branch inclination angle, density, and rigidity (Brauman et al. 2010; Levia and Germer, 2015) as well as hydrophobicity (Rosado and Holder, 2013), may also affect TF sensitivity.

Although the consistently-observed strong correlation between stand-scale $\mathrm{TF}$ and storm amount across forest types and climates confirms that storm amount is the primary factor affecting TF generation after canopy structures are saturated (Levia et al. 2011), the degree to which stand-scale TF responds to storm amount has been linked to vegetation structure (leaf area index, crown depth, etc.) (Staelens et al. 2008; Toba and Ohta 2005). Consequently, it is advisable to incorporate vegetation characteristics with $\mathrm{TF}$ sensitivity in response to changes in $\mathrm{P}_{\mathrm{g}}$ responses in future investigations.

\subsection{Throughfall sensitivity and climate projections}

Changes in $\mathrm{P}_{\mathrm{g}}$ to an area are expected to be compounded by the TF sensitivity of each forest type. An example "rough" estimation using the $17 \%$ increase in Pg predicted by RCP 2.6 scenario in the Mediterranean climate results in a $20 \%$ and $15 \%$ increase in $\mathrm{TF}$ generation in $\mathrm{CS}$ and $\mathrm{QC}_{3}$ forests, respectively. The projected 3.0\% increase (by RCP 2.6) and 5\% decrease (by $\mathrm{RCP} 8.5$ ) in mean $\mathrm{P}_{\mathrm{g}}$, however, in the very humid climate of Iran where the Caspian forests are located (Table 5) is not anticipated to significantly alter TF supply to the forest floor due to the tree species' low sensitivity (Fig. 2).

Our analysis suggests that the projections under the two different scenarios are dissimilar in the arid climate and similar in the semi-arid climate. The RCP 2.6 scenario projects a large $(46 \%)$ increase in annual precipitation in the arid climate from 2020-50, but only a $24 \%$ increase in the RCP 8.5 scenario (Table 5). In contrast, in the semi-arid climate type, both scenarios predict roughly the same percent of decrease in yearly precipitation (-15\% for RCP 2.6 and $-14 \%$ for RCP 8.5$)$. The

\section{CONCLUSION}

This national assessment of TF sensitivity to storm magnitude for common forest types in Iran showed large fluctuations in TF sensitivity for species planted in different climates. Arid needleleaved plantations exhibited generally higher sensitivity responses to changing storm amount, while very humid, natural broad-leaved forests had low sensitivity responses. Projections of mean storm magnitude under a low emission scenario indicated that, compared to historical data, modest changes would be expected for most climates (excluding semi-arid and arid) on average during 2020-2050. However, under a high emission scenario, larger alterations are expected in the semiarid and arid types. Results indicate that any projected change in storm size will not simply be translated directly to a change in throughfall. Rather, the increase or decrease in throughfall amount may be better predicted as a product of the projected change in storm magnitude and the forest-specific throughfall sensitivity. The results from both scenarios present an examination of the throughfall sensitivity to climate change for distinctive afforestations in diverse climates of Iran, and can be a reference for water managers and planning associated with adaptation. These findings have implications for selection of the most appropriate and adapted species for afforestation under climate change. projected increase in annual precipitation (124 $\mathrm{mm}$ for historical vs $181 \mathrm{~mm}$ under RCP 2.6 scenario and $167 \mathrm{~mm}$ under RCP 8.5 scenario) supports past work that suggests the total precipitation in the dry regions are projected to continuously increase over the twenty-first century (Markus et al. 2016). RCP 2.6 scenario indicated that the average change in mean $\mathrm{Pg}_{\mathrm{g}}$ size is expected to decrease by $-10 \%$ in the arid and $-26 \%$ in the semi-arid climate (Table 5).

Fewer impacts may be realized in the semi-humid climate where the dominant tree species showed low TF sensitivity and insignificant changes in mean event size are predicted by both RCPs. Clearly, these climate change scenarios (and others) can be a reference for setting minimum and maximum configurations of forest cover in water management and planning associated with adaptation. There will be large uncertainty among GCM models, most GCM models may have different performances across regions, and, as a consequence of lacking large scale observations, downscaling from GCM grid data to local areas is difficult. Moreover, the delta change factor strategy used in this study does not adjust climate projections, but assumes that the signal or changes are reasonably projected by climate models, even though the models are biased (Leng \& Tang, 2014). A key

feature of this approach is that, because the method uses historical precipitation as its basis and GCM data only to change the magnitude of the historical precipitation, it fails to account for changes in $\mathrm{P}$ variability predicted by different GCM models (Leng \& Tang, 2014). Still, the projections and downscaling of changes in $\mathrm{P}_{\mathrm{g}}$ under the most conservative (low emission) and the highest greenhouse gas emissions pathway (high emission) scenarios (Table 5) underscores the necessity of work to understand TF sensitivity of common forest types in a region.

\section{ACKNOWLEDGMENT}

This research was supported by funding from Iran National Science Foundation (INSF) (Grant number: 96001633) and the International Partnership Program of Chinese Academy of Sciences (131A11KYSB20170113) in the frame of Silk Road Science Fund (SRSF) 2018.

\section{REFERENCES}

Abbasian, P., Attarod, P., Sadeghi, S.M.M., Van Stan II, J.T., Hodjati, S,M., 2015. Throughfall nutrients in a degraded indigenous Fagus orientalis forest and a Picea abies plantation in North of Iran. Forest Syst 24 (3) e035, doi//dx.doi.org/10.5424/fs/2015243-06764.

Attarod, P., Kheirkhah, F., Khalighi Sigaroodi, Sh., Sadeghi, S.M.M., 2015a. Sensitivity of reference evapotranspiration to global warming in the Caspian region, North of Iran. J Agr Sci Tech-Iran 17: 869-883.

Attarod, P., Sadeghi, S.M.M., Pypker, T.G., Bagheri, H., Bagheri, M., Bayramzadeh, V., 2015b. Needle-leaved trees 
impacts on rainfall interception and canopy storage capacity in an arid environment. New Forest 46: 339-355.

Baltas, E., 2007. Spatial distribution of climate indices in northern Greece. Meteorol Appl 14: 69-78.

Chung, S.O., Nkomozepi, T., 2012. Uncertainty of paddy irrigation requirement estimated from climate change projections in the Geumho River basin, Korea. Paddy Water Environ 10: 175-185, doi: 10.1007/s10333-011-0305-z.

Crockford, R.H., Richardson, D.P., 2000. Partitioning of rainfall into throughfall, stem-flow and interception: effect of forest type, ground cover and climate. Hydrol Process 14: $2903-2920$.

Friesen, J., Lundquist, J., Van Stan II, J.T., 2015. Evolution of forest precipitation water storage measurement methods. Hydrol Process 29: 2504-2520.

Goyal, R.K., 2004. Sensitivity of evapotranspiration to global warming: a case study of arid zone of Rajasthan (India). Agr Water Manage 69: 1-11.

Huntingford, C., Zelazowski, P., Galbraith, D., Mercado, L.M., Sitch, S., Fisher, R., Lomas, M., Walker, A., Jones, C., Booth, B., Malhi, Y., Hemming, D., Kay, G., Good, P., Lewis, S., Philips, O., Aktin, O., Lioyd, O., Gloor, E., Zaragoza-Castells, J., Meir, P., Betts, R., Harris, P., Nobre, C., Marengo, J., Cox, P., 2013. Simulated resilience of tropical rainforests to $\mathrm{CO}_{2}$-induced climate change. Nature Geoscience 6: 268-273. doi: 10.1038/ngeo1741.

Hempel, S., Frieler, K., Warszawski, L., Schewe, J., Piontek, F., 2013. A trend-preserving bias correction - the ISI-MIP approach. Earth Syst Dynam 4(2): 219-236.

Huntington, T.G., 2006. Evidence for intensification of the global water cycle: review and synthesis. J Hydrol 319: 8395 .

Jazirei, M.H., 2009. Dryland Afforestation. University of Tehran Press, Iran. pp 560. ISBN 978-964-03-6122-1.

Jones, C.D., Hughes, J.K., Bellouin, N., Hardiman, S.C., Jones, G.S., Knight, J., Liddicoat, S., O'Connor1, F.M., Andres, R.J., Bell, C., Boo, K.-O., Bozzo, A., Butchart, N., Cadule, P., Corbin, K.D., Doutriaux-Boucher, M., Friedlingstein, P., Gornall, J., Gray, L., Halloran, P.R., Hurtt, G., Ingram, W.J., Lamarque, J.F., Law, R.M., Meinshausen, M., Osprey, S., Palin, E.J., Parsons Chini, L., Raddatz, T., Sanderson, M.G., Sellar, A.A., Schurer, A., Valdes, P., Wood, N., Woodward, S., Yoshioka, M., Zerroukat, M., 2011. The HadGEM2-ES implementation of CMIP5 centennial simulations. Geoscie Model Dev 4(3): 543-570. doi: 10.5194/gmd-4-543-2011.

Leng, G., Tang, Q., 2014. Modeling the impacts of future climate change on irrigation over China: sensitivity to adjusted projections. J Hydrometeorol 15(5): 2085-2103, doi: 10.1175/JHM-D-13-0182.1.

Levia, D.F., Frost, E.E., 2006. Variability of throughfall volume and solute inputs in wooded ecosystems. Prog Phys Geog 30: 605-632. doi: 10.1177/0309133306071145.
Levia, D.F., Keim, R.F., Carlyle-Moses, D.E., Frost, E.E., 2011. Throughfall and stemflow in wooded ecosystems, in Forest Hydrology and Biogeochemistry: Synthesis of Past Research and Future Directions, Ecol. Studr. Ser., vol. 216, edited by D. F. Levia, D. E. Carlyle-Moses, and T. Tanaka, pp. 425-443, Springer, Heidelberg. doi: 10.1007/978-94007-1363-5_21.

MGovern, M., Pasher, J., 2016. Canadian urban tree canopy cover and carbon sequestration status and change 1990-2012. Urban For Urban Gree 20: 227-232. https://doi.org/10.1016/j.ufug.2016.09.002

Motahari, M., Attarod, P., Pypker, T.G., Etemad, V., Shirvany, A., 2013. Rainfall interception and canopy storage capacity of a Pinus eldarica plantation in a semi-arid climate zone: an application of the Gash model. J Agr Sci Tech-Iran 15: 981-994.

Muzylo, A., Llorens, P., Domingo, F., 2012. Precipitation partitioning in a deciduous forest plot in leafed and leafless periods. Ecohydrology 5: 759-767.

Pypker, T.G., Levia, D.F., Staelens, J., Van Stan II, J.T., 2011. Canopy structure in relation to hydrological and biogeochemical fluxes. XVII. In: Levia, D.F., Carlyle-Moses, D.E., Tanaka, T. (Eds.), Forest Hydrology and Biogeochemistry: Synthesis of Past Research and Future Directions. Ecological Studies Series, No. 216. SpringerVerlag, Heidelberg, pp. 371-388.

Rutter, A.J., Morton, A.J., Robins, P.C., 1975. A predictive model of rainfall interception in forests II. Generalization of the model and comparison with observations in some coniferous and hardwood stands. J Appl Ecol 12: 367-380.

Sadeghi, S.M.M., Attarod, P., Van Stan II, J.T., Pypker, T.G., Dunkerley, D., 2015. Efficiency of the reformulated Gash's interception model in semiarid afforestations. Agr Forest Meteorol 201: 76-85.

Sagheb Talebi, K., Sajedi, T., Pourhashemi, M., 2014. Forests of Iran, A treasure from the past, a hope for the future. Plant and Vegetation 10, Springer, pp, 149. doi 10.1007/978-94-007-7371-4_1.

Shahid, S., 2011. Impacts of climate change on irrigation water demand in northwestern Bangladesh. Climatic Change 105: 433-453. doi: 10.1007/s10584-010-9895-5.

Singh, V.P., Xu, C-Y., 1997. Sensitivity of mass transferbased evaporation equations to errors in daily and monthly input data. Hydrol Process 11: 1465-1473.

Staelens, J., Schrijver, A,D, Verheyen, K,, Verhoest, N.E.C., 2008. Precipitation partitioning into throughfall, stemflow, and interception within a single beech (Fagus sylvatica L.) canopy: influence of foliation, rain event characteristics, and meteorology. Hydrol Process 2: 33-45. 10.1002/hyp.6610.

Sun, G., Zhou, G.Y., Zhang, Z.Q., Wei, X.H., McNulty, S.G., Vose, J.M., 2006. Potential water yield reduction due to forestation across China. J Hydrol 328: 548-558. 
Toba, T., Ohta, T., 2005. An observational study of the factors that influence interception loss in boreal and temperate forests. J Hydrol 313: 208-220.

Tollefson, J., 2016. Global warming already driving increases in precipitation extremes. Nat doi:10.1038/nature.2016.19508.

U1 Hassan, M., Qureshi, A.S., Heydari, N., 2007. A proposed framework for irrigation management transfer in Iran: Lessons from Asia and Iran. Colombo, Sri Lanka: International Water Management Institute. 37 pp. (IWMI Working Paper 118)

Valente, F., David, J.S., Gash, J.H.C., 1997. Modelling interception loss for two sparse eucalypt and pine forests in central Portugal using reformulated Rutter and Gash analytical models. J Hydrol 190: 141-162.

Wang, Y.H., Yu, P., Feger, K.H., Wei, X., Sun, G., Bonell, M., Xiong, W., Zhang, S., Xu, L., 2011. Annual runoff and evapotranspiration of forestlands and non-forestlands in selected basins of the Loess Plateau of China. Ecohydrology 4: 277-287.

Zhang, Z., Zhao, Y., Li, X., Huang, L., Tan, H., 2016. Gross rainfall amount and maximum rainfall intensity in 60-minute influence on interception loss of shrubs: a 10-year observation in the Tengger Desert. Sci Rep-UK 6:26030 doi: 10.1038/srep26030. 